\title{
EFFECT OF HONEY ON SPERM CHARACTERISTICS AND PREGNANCY RATE IN MICE
}

\author{
Ilaf Hassan Hadi \\ Department of Anatomy, College of Medicine, Al-Iraqia University, \\ Baghdad, Iraq \\ E-mail: Ilaf.hadi014@gmail.com
}

Received Date: 30/11/2016

\section{ABSTRACT}

The aim of the current study is to demonstrate the effect of honey on the sperms characteristics (sperm concentration, sperm motility, grade of activity and sperm normal morphology) as well as pregnancy rate in mice. Sperms were obtained from caudal epididymis of male mice and prepared by adding $10 \%$ of honey to the IVF medium using direct sperms activation technique for 30 minute incubation period before artificial insemination.

The study revealed a significant $(\mathrm{P}<0.05)$ increase in active sperm motility (grade A and grade B) $49 \%$ and pregnancy rate $53.3 \%$ in female mice artificially inseminated with sperms. On the other hand, there were no significant differences in sperm concentrations and normal sperm morphology. In conclusion, the honey was beneficial in improving male fertility of mice by enhancing sperm motility and pregnancy rate of female mice.

Keywords: Honey, Mice, Pregnancy, Sperm characteristics, Sperm motility.

\section{INTRODUCTION}

Honey is a natural product of many floral nectar, its flavors and activity varies based on its origin and processing methods (Mahaneem et al., 2010).Honey has many nutrient sources like those available in fruits which become alkaline in stomach (Bradley, 2010). Honey has been used as nutritive sweetener and a healing agent from ancient times, (Estevinho et al., 2008). It contains sugars, trace amount of minerals as well as vitamins (Syazana et al., 2011). Recently, many studies have reported the valuable effects of honey on surgical and medical treatments. Honey has been demonstrated to have many biological advantages such as antibacterial, antifungal, antiseptic and anti-inflammatory (Tan et al., 2009), and it also contains many components thought to serve as antioxidants (Viuda-Martos et al., 2005). It has also wound healing properties, burns and the treatment of diabetic ulcers (Cooper, 2001, Eddy and Gideon, 2005) Histological studies have been reported that application of honey to wounds reduces inflammation in superficial and deep wounds (Postmes et al., 1997) as well as in burns (Burlando, 1978).Honey is said to have increased thickness of vaginal epithelium and muscle, without effecting circulating hormones, such as testosterone or gonadotropins (Mahaneem et al., 2008), and is useful to treat vaginal dryness and atrophy in postmenopausal women (Mahaneem et al., 2007). Regarding male reproduction semen quality can be affected by genetic, behavioral, physiological (Skakkebaek et al., 1994) and environmental factors (Sikka and Wang, 2008). Honey contains fructose and glucose which provide body with energy, thereby increasing testosterone and libido (Austin, 2012) and improving sexual 
Effect of honey on sperm characteristics and pregnancy rate in Mice

virility (Bradley, 2010). Honey was reported to enhance spermatogenesis in rats if given at the appropriate dose (Mahaneem et al., 2007) and reduce the toxicity of cigarette smoke during spermatogenesis (Mahaneem et al., 2008). Honey affects spermatogenesis by activating sorbitol dehydrogenase (SDH) and inhibiting lactate dehydrogenase (LDH) (Salam et al., 2008). World Health Organization (WHO) sperm analysis criteria (World Health Organization, 1999) stated that concentration of $20 \times 10 \mathrm{sperms} / \mathrm{ml}$ or higher, percentage of normal sperm not lower than 30 and $50 \%$ of progressive motile sperm or more within 1hour of ejaculation are compatible with male fertility.

The objective of the current study was to determine the influence of honey on sperm function parameters and pregnancy rate by adding $0.1 \mathrm{ml}$ of honey suspension to $0.9 \mathrm{ml}$ of sperm's culture media.

\section{Sperm collection}

\section{MATERIALS AND METHODS}

Twenty mature male mice and 60 female mice (Balb/C St Can BR Strain) of 8-12 weeks old were included in the current study at Al-Iraqia University-College of Medicine from May 2015 to November 2015.

Sperms were pooled from male mice, sacrificed by cervical dislocation. Two caudal epididymis were dissected and minced in $1 \mathrm{ml}$ of IVF medium with 30-gauge needle syringe to permit the sperms to swim-out (Pl.1) (Erbach et al., 1994). The spermatozoa suspensions were divided into two parts.

\section{Sperms activation In vitro}

The first part (control group):

The caudal epididymis sperms were allowed to swim-up through 30 minutes in incubator at $37{ }^{\circ} \mathrm{C}$ in $5 \% \mathrm{CO}_{2}$ with $1 \mathrm{ml}$ of IVF medium. Then the sperms were counted and used to inseminate the control group (Erbach et al., 1994).

\section{Honey-media preparation}

Ten percent concentration of honey were prepared by adding $0.1 \mathrm{ml}$ of honey suspension to $0.9 \mathrm{ml}$ of IVF media, filtered using filters with pore size $0.45 \mu \mathrm{m}$ (Mahaneem et al., 2010), and permit the second part of spermatozoa suspensions to swim-out. Sperms were examined under the high-resolution objective of light microscope to evaluate the final motile sperm concentrations and morphology (Pl. 2) and prepared for inseminated the treated group (Duselis and Vrana, 2007).The motility of each spermatozoon encountered was graded:-

-A- linear and rapid progressive motility.

-B - Rapid non- linear or non- rapid progressive motility.

-C-Localized motility.

-D- Immotile.

\section{Artificial Insemination}

The pregnancy rate was gained by dividing the number of pregnant mice on the total number of inseminated mice. There were 30 female mice inseminated by the sperms activated with $10 \%$ honey-IVF medium (treated group). Artificial Insemination (AI) was performed during estrous phase. A blunt 22-gauge needle syringe (1.5 inch long) was needed to sperm administration. A $120^{\circ}$ bend was placed about $3 / 4^{\text {th }}$ the way down the needle. An assistant is 


\section{Ilaf H. Hadi}

used to hold the female in the suitable position, the needle up to the bend was inserted into the vagina and $0.025-0.05 \mathrm{mls}$ of sperms suspensions injected (Pl. 3) (Duselis and Vrana, 2007).

\section{Statistical analysis:}

Data of mice sperm fluid analysis for the treated and for the control groups were expressed as mean $\pm \mathrm{SE}$ and were analyzed using paired sample t-test. While Chi-square test was used to compare the pregnancy rate values from treated and control groups. P-value $<0.05$ was considered for significant means (Sorlie, 1995).

\section{RESULTS}

The results of sperm characteristics (sperm concentration, sperm motility, grade of activity and sperm normal morphology) following in vitro activation and incubation of caudal epididymis region for 30 min using IVF medium with and without $10 \%$ honey were observed in table (1).The sperm concentrations $\left(\times 10^{6}\right.$ sperm/ $\left.\mathrm{ml}\right)$ following direct activation with $10 \%$ honey-IVF medium showed no significant difference as compared with the honey-free IVF medium.

Active sperm motility (grade A and grade B) in treated group was $49 \%$ significantly higher as compared with the control group. The percentage of normal sperms morphology in treated group was 33\%. However, the differences between two groups lacked significance.

The pregnancy rate in treated group was $53.3 \%$ (16 pregnant mice out of 30 inseminated mice), while it was $40 \%$ (12 pregnant mice out of 30 inseminated mice) for control group. There was significant $(\mathrm{P} \leq 0.05)$ increase in pregnancy rate between two groups (Tab. 1).

Table (1): Comparison between control and treated groups with $10 \%$ honey-IVF medium on certain sperm properties and pregnancy rate in mice (Means $\pm \mathrm{SE}$ ).

\begin{tabular}{|c|c|c|c|c|c|c|}
\hline \multirow{2}{*}{ 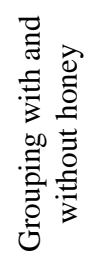 } & \multicolumn{5}{|c|}{ In vitro sperm activation } & \multirow{2}{*}{ 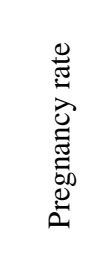 } \\
\hline & $\begin{array}{c}\text { Sperm } \\
\text { concentration } \\
\left(10^{6} / \mathrm{ml}\right)\end{array}$ & $\begin{array}{c}\text { Sperm } \\
\text { motility } \\
\text { grade } \mathrm{A}(\%)\end{array}$ & $\begin{array}{c}\text { Sperm } \\
\text { motility } \\
\text { grade B }(\%)\end{array}$ & $\begin{array}{c}\text { Progressive } \\
\text { motility } \\
(\mathrm{A}+\mathrm{B}) \%\end{array}$ & $\begin{array}{c}\text { Normal } \\
\text { morphol } \\
\text { ogy } \\
(\%)\end{array}$ & \\
\hline $\begin{array}{l}\text { control } \\
\text { group }\end{array}$ & $27.62 \pm 5.301$ & $15.30 \pm 2.203$ & $21.22 \pm 1.201$ & $36.52 \pm 1.202$ & $\begin{array}{c}32.72 \pm 1 \\
.531\end{array}$ & $\begin{array}{l}12 / 30 \\
(40 \%)\end{array}$ \\
\hline $\begin{array}{l}\text { treated } \\
\text { group }\end{array}$ & $28.22 \pm 5.351$ & $20.30 \pm 0.021$ & $29.20 \pm 2.105$ & $49.50 \pm 3.032$ & $\begin{array}{c}33.12 \pm 4 \\
.103\end{array}$ & $\begin{array}{c}16 / 30 \\
(53.3 \%)\end{array}$ \\
\hline$p$-value & NS & S & $S$ & $S$ & NS & $S$ \\
\hline
\end{tabular}

S: significant at 0.05 levels

NS: non-significant at 0.05 levels 
Effect of honey on sperm characteristics and pregnancy rate in Mice

\section{DISCUSSION}

The present study, showed that the adding of honey at $10 \%$ to the culture media improves sperm parameters following 30 minutes, mainly total sperm motility, percentage and grade activity of forward progressive movement. Culturing of the semen sample with $10 \%$ honeyIVF medium before insemination result in a significant increase in the percentages of sperm motility and grade activity of forward movement to reach in the last one to $49 \%$ (Grade A+ Grade B) of the semen sample. Honey is rich in sugars such as fructose and glucose, in addition to the minerals like potassium, magnesium, calcium, sodium chloride, sulfur, ferrous, zinc, phosphates and vitamins C, B1, B2, B3, B5 and B6. All these substances stimulate sperm motility and the grade activity of forward movement (Estevinho et al., 2008 and Syazanaet al., 2011).

Minerals especially $\mathrm{Ca}+2$ are known to inhibit the enzyme phosphate diestrase, and these will prevent cAMP degradation and consequently increase sperm motility (Nassar et al., 1998).

Furthermore, honey contains carbohydrates and also has sugars like: glucose, fructose (Estevinho et al., 2008), and these sugars are considered to be a source of energy for sperm motility. Abdul-Ghani et al. (2008) suggested that honey can affect the spermatogenesis by activating testicular marker enzymes like sorbitol dehydrogenase by $31 \%$ and inhibited lactate dehydrogenase by $48 \%$, which has been indicated to increase its activity in infertility cases (Eliasson and Virji, 1985). During carbohydrate metabolism, sorbitol dehydrogenase converts sorbitol, the sugar alcohol form of glucose, into fructose (El-Kabbani et al., 2004). Honey is rich in fructose, which is an important marker in the seminal fluid, and provides energy and nutrients for the sperm and maintain perfect alkaline medium for their viability and motility. Honey is full of enzymatic and non-enzymatic antioxidants, and contains pinostrobin, pinocembrin, ascorbic acid, vitamins E, diastase, glucose oxidase (Erejuwa et al., 2012). It acts against lipid peroxidation and oxidative stress by ROS such as, hydrogen peroxide, super oxide, and prevents oxygen contact with unsaturated fatty acids in the sperm plasma membrane (Syazana et al., 2011).

The data of the study also demonstrated that, there is no significant difference in the normal morphological sperms between the treated and control groups, and the mean was close to $33 \%$ as an average. These results are consistent with the improvements in sperm grade activity of forward movement; because it is very difficult to make any improvement on either sperm parameters when the semen sample is considered morphologically abnormal (Coetzee et al., 1998).

The results of this study showed a significant increase in the pregnancy rate, and the differences in the means were $13 \%$ between the treated and control groups. Hence it is a good percentage of difference in the fields of experimental embryology and ARTs, and there were a lot of factors that might meddle with this observation; the study found that, there is a significant increase in the total active sperm after direct activation with $10 \%$ honey-IVF medium; all the female mice in this study were inseminated with the similar sperm concentrations. Therefore, the differences in pregnancy rate here are not due to the improvements in the sperm concentrations but it may belong to the effect of the direct activation technique with $10 \%$ honey and to the decrease in the insemination volume $(0.025$ $0.05 \mathrm{mls}$ ) injected to each female (insemination volume was reduced to overcome with that present). This reduction may decrease the decapacitation factors and contamination from the seminal plasma, such as cellular debris, mycoplasmas, chlamydia, trichomonas, bacteria, and 


\section{Ilaf H. Hadi}

different blood cells, such as RBCs and WBCs (Jeyendran and Zhang, 2003).The other important factor is sperm motility. The study showed that the pregnancy rate increases with an increasing sperm cell motility. This finding agreed with Kasai et al. (2002), who demonstrated that one of crucial parameter that could provide treatment outcome was the percentage of motile sperm after proper preparation.

Other vital parameter is sperm morphology that may assume a part to acquire the high rate of FR. Sperm normal morphology had been proven as a good indication for in vivo fertilization (Menkveld et al., 1990; van Zyl et al., 1990) and assisted reproduction (Coetzee et al., 1998). Many studies had reported a significant relationship between sperm ability to penetrate the zonapellucida and its morphology and motility (Liu and Baker, 1992); and also it found a powerful correlation between the acrosome reaction and normal sperm morphology and successful fertilization (Menkveld et al., 2003), and increased fertility percentages consequently.

The direct activation technique didn't provide immotile, dead sperm and residual cytoplasmic droplet washing. Thus, even in the samples with good sperm morphology, there was high level of ROS, and that agreed with Keating et al. (1997) who correlated with the extensive production of ROS and presence of a residual cytoplasmic droplet that significantly affected sperm fertilizing ability. Moreover, the cytoplasmic residues cause a higher content of cytoplasmic enzymes, such as glucose- 6-phosphate dehydrogenase or creatine kinase (Gomez et al., 1996), which promote the generation of free radicals in the sperm cells themselves (Aitken et al., 1997).

The other factor that may meddle with the increments in pregnancy rate was the addition of $10 \%$ of honey to the insemination medium which provided a wide range of active ingredients that gave a nourishment and/or protection to the oocytes and early cleaved embryos. Honey has antioxidant properties (Viuda-Martos et al., 2005). Antioxidant compounds may counteract the action of ROS on epididymal sperm parameters and therefore on fertilization rate, the balance between ROS generation and antioxidant capacity in the semen plays a crucial role on sperm functions parameter, fertilization and pregnancy procedures (Agarwal et al., 2005).This observation is in Line with Pasqualotto et al. (2000), who confirmed that infertile patients did not only have excessive production of ROS, but also have a defect in the antioxidant system.

The present study showed that adding of $10 \%$ honey to the culture media increased semen quality through improving the sperm parameters following 30 minutes of activation, and improving post insemination pregnancy rate. Thus, honey furthermore varies advantages, also has positive effects on the male reproductive system. 
Effect of honey on sperm characteristics and pregnancy rate in Mice

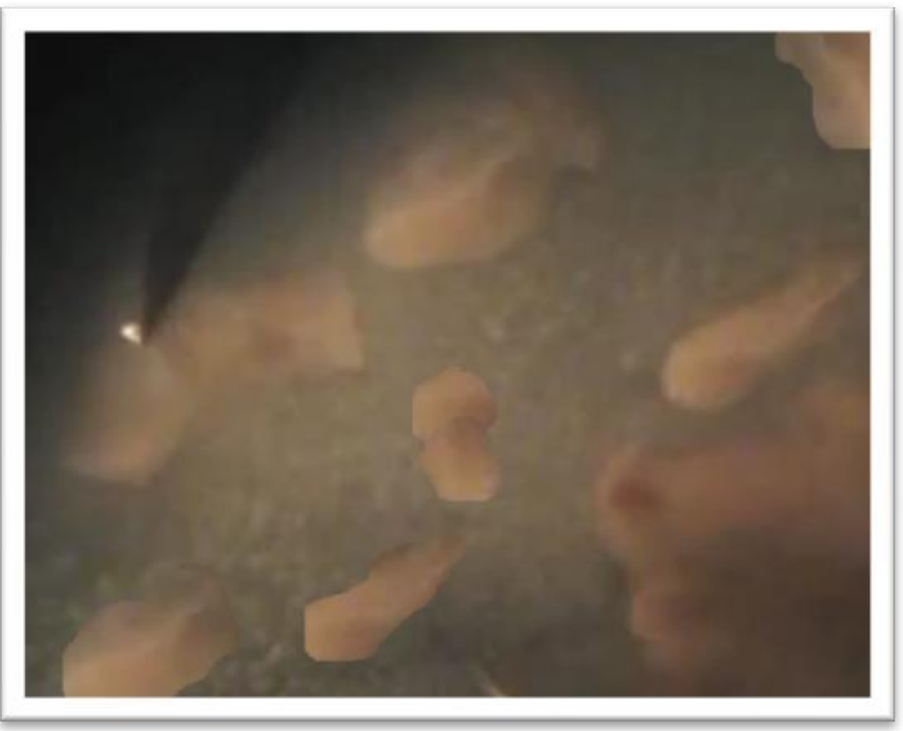

Plate (1): Mincing the caudal epididymis

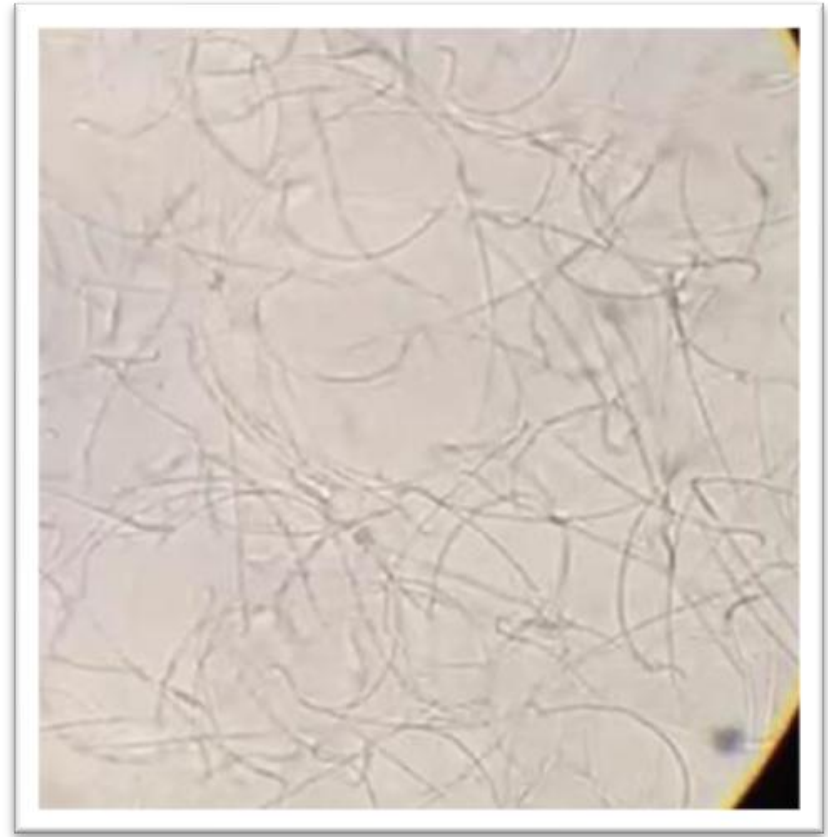

Plate (2): Sperms under a microscope after activation 
Ilaf H. Hadi

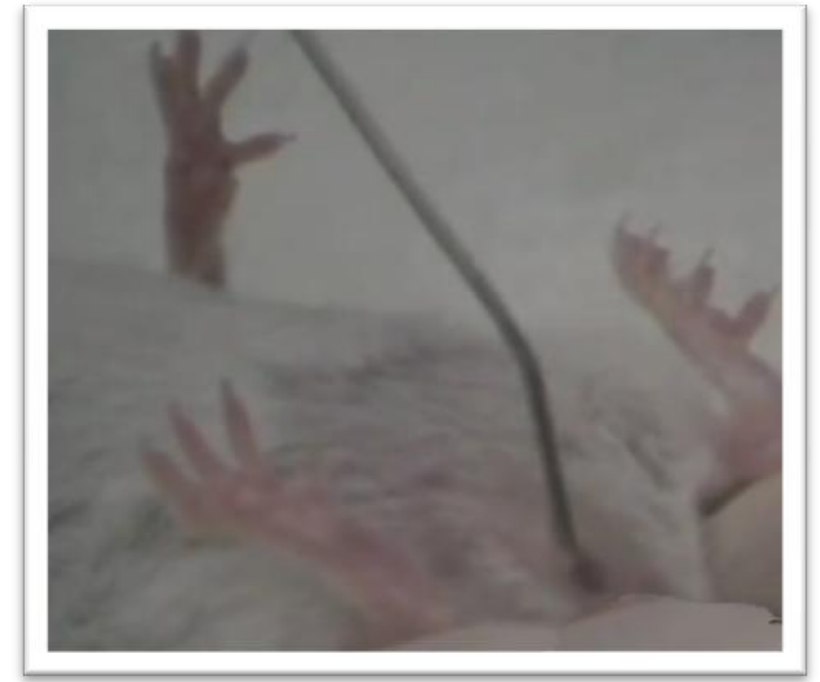

Plate (3): Artificial Insemination

\section{LITERATURE CITED}

Abdul-Ghani, A.S., Dabdoub, N., Muhammad, R., Abdul-Ghani, R. and Qazzaz, M. 2008. Effect of Palestinian honey on spermatogenesis in rats. Journal of Medicinal Food, 11 (4):799-802.

Agarwal, A., Gupta, S. and Sharma, R.K. 2005. Role of oxidative stress in female reproduction. Indian Journal of Experimental Biology, 3:28-31.

Aitken, R.J., Fisher, H.M. and Fulton, N. 1997. Reactive oxygen species generation by human spermatozoa is induced by exogenous NADPH and inhibited by the flavoprotein inhibitors diphenyleneiodonium and quinacrine. Molecular Reproduction and Development, 47: 468-482.

Austin, S. 2012. Sexual performance natural supplements for boost sexual libido. Human Reproduction Update, 2: 62-71.

Bradley, P.R. 2010. Raw honey and cinnamon. Bournemouth, British Herbal Medicine Association, 1:145-148.

Burlando, F. 1978. Glucose and the culture of human embryos. Fertility Sterility, 113: 699706.

Coetzee, K., Kruger, T.F. and Lombard, C.J. 1998. Predictive value of normal sperm morphology: a structured literature review. Human Reproduction Update, 4: 7382.

Cooper, R. 2001. How does honey heal wounds? In: Honey and Healing (Munn P, Jones R, Eds.). IBRA International bee research association, Cardiff, UK, 27-34. 
Effect of honey on sperm characteristics and pregnancy rate in Mice

Duselis, A.R. and Vrana, P.B. 2007. Harvesting sperm and artificial insemination of mice.Archives of Andrology, 1 (3):184.

Eddy, J.J. and Gideon, M.D. 2005. Topical honey for diabetic foot ulcers. Journal of Fam Practical, 54: 533-535.

Eliasson, R. and Virji, N. 1985. LDH-C4 in human seminal plasma and its relationship to testicular function II.Clinical aspects. International Journal of Andrology, 8(3): 201-214.

El-kabbani, O., Darmanin, C. and Chung, R.P.T. 2004. Sorbitol dehydrogenase: structure, function and ligand design. Current medicinal chemistry, 11(4): 465-476.

Erbach, G.T., Lawitts, J.A., Papaioannou, V.E. and Biggers, J.D. 1994. Differential growth of the mouse preimplantation embryo in chemically defined media. Biological Reproduction, 50:1027-1033.

Erejuwa, O.O., Sulaiman, S.A. and Wahab, M.S.A.B. 2012. Honey: A novel antioxidant. Molecules, 17: 4400-4423.

Estevinho, L., Pereira, A., Moreira, L., Dias, L. and Pereira, E. 2008. Antioxidant and antimicrobial effects of phenolic compounds extracts of Northeast Portugalhoney. Food and Chemical Toxicology, 46: 3774-3779.

Gomez, E., Buckingham, D., Brindle, J., Lanzafame, F., Irvine, D.S. and Aitken, R.J. 1996. Development of an image analysis system to monitor the retention of residual cytoplasm by human spermatozoa: correlation with biochemical markers of the cytoplasmic space, oxidative stress and sperm function. Journal of Andrology, 17: 276- 287.

Jeyendran, R.S. and Zhang, X.J. 2003. Sperm processing methods. In: Jeyendran R.S. (Ed.): Sperm collection and processing methods: A Practical guide. cambridge University press, $107-110$.

Kasai, T., Ogawa, K. and Mizuno, K. 2002. Relationship between sperm mitochondrial potential, sperm motility and fertility potential. Asian Journal of Andrology, 4: $97-103$.

Keating, J., Grundy, C.E., Fivey, P.S., Elliot, M. and Robinson, J. 1997. Investigation of the association between the presence of cytoplasmic residues on the human sperm midpiece and defective sperm function. Journal of Reproduction and Fertility, 110: 71-77.

Liu, D.Y. and Baker, H. 1992. Morphology of spermatozoa bound to the zonapellucida of human oocytes that failed to fertilize in vitro. Journal of Reproduction and Fertility, 94: 71-84.

Mahaneem, M., Siti, M., Yatiban, K. and Hasnan, J. 2007. Effect of Tualang on spermatogenesis in rats (Abstract). Malay Journal of Medical Science, 14(1): 126. 


\section{Ilaf H. Hadi}

Mahaneem, M., Siti, A.S., Islam, M.N., ZolIzhar, M.I.,Yatiban, M.K. and Nasir, A. 2008. A pilot study to compare the effect of honey on spermatogenesis in rats exposed to cigarette smoke (Abstract). Malay Journal of Medical Science, 14(1): 126.

Mahaneem, M., Sulaiman, S., Jaafar, H., Sirajudeen, K., Ismail, Z. and Islam, N. 2011. Effect of honey on testicular functions in rats exposed to cigarette smoke. Journal of Apiproduct and Apimedical Science, 3(1): 12 - 17.

Menkveld, R., El-Garem, Y., Schill, W.B. and Henkel, R. 2003. Relationship between acrosomal function and sperm morphology. Journal of Assisted Reproduction and Genetics, 20: 432-438.

Menkveld, R., Stander, F.S., Kotze, T.J., Kruger, T.F. and van Zyl, J.A. 1990.The evaluation of morphological characteristics of human spermatozoa according to stricter criteria. Human Reproduction, 5: 586-592

Nassar, A., Mahony, M., Blackmore, P., Morshedi, M. and Ozgur, K. 1998. Increase of intracellular calcium is not cause of Penteoxifylline-induced hyperactivation or acrosome reaction in human sperm. Fertility Sterility, 69: 745-749.

Pasqualotto, F.F., Sharma, R.K., Nelson, D.R., Thomas, A.R. and Garwal, A. 2000. Relationship between oxidative stress, semen characteristics, and clinical diagnosis in men undergoing infertility investigation. Fertility Sterility, 73: 459464.

Postmes, T.J., Bosch, R., Dutrieux, R., and Hoekstra, M.J. 1997. Speeding up the healing of burns with honey.An experimental the healing of burns with honey.An experimental biopsies. In: Mizrahi, A., Lensky, Y., eds. Bee Products: Properties, Applications and Apitherapy. New York: Plenum Press, p27-37.

Sikka, S.C. and Wang, R. 2008. Endocrine disruptors and estrogenic effects on male reproductive axis. Asian Journal of Andrology, 10:134-145.

Skakkebaek, N.E, Giwercman, A. and De-krester, D. 1994. Pathogenesis and management of male infertility. The Lancet, 343: 8911.

Sorlie, D.E. 1995. Medical biostatistics: Examination and board review. Norwalk. Connecticut. Appleton and lang, p 47-88.

Syazana, N.S., Hashida, N.H., Majid, A.M., Sharifah, H.A.D. and Kamaruddin, M.Y. 2011. Effects of gelam honey on sperm quality and testis of rat. Sains Malaysiana, 40(11):1243-1246.

Tan, H.T., Abdul Rahman, R., Gan, S. H., Halim, A. S., Hassan, S. A., Suleiman, S.A. and Kirpin-Kaur, B.S. 2009. Antibacterial properties of Malaysian tualang honey against wound and enteric microorganisms in comparison to manuka honey. BMC complementary and Alternative Medicine, 9 (1):34-45.

van Zyl, J.A., Kotze, T. and Menkveld, R. 1990. Predictive value of spermatozoa morphology in natural fertilization. In: Acosta, A.A., Swanson, R.J., Ackerman, S.B., Kruger, 
Effect of honey on sperm characteristics and pregnancy rate in Mice

T.F., van Zyl, J.A. and Menkveld, R. (Eds.): Human spermatozoa in assisted reproduction. Williams \& Wilkins. Baltimore, 319-324.

Viuda-Martos, M., Navajas, Y.R., Fernandez-Lopez, J. and Perez-Alvarez, J.A. 2005. Functional properties of honey, propolis and royal jelly. Journal of Food Science, 73(9):R117-R124.

World Health Organization. 1999. WHO laboratory manual for the examination of Human semen and sperm cervical inverse interaction, 4. Edition, Cambridge University Press, Cambridge. 
Ilaf H. Hadi

Bull. Iraq nat. Hist. Mus.

(2017) 14 (3): 223-233

تأثثر العسل في خصائص النطف ومعدل الحمل لاى الفئران

إيلاف حسن هادي الطي

فرع التشريح، كلية الطب، الجامعة العر اقية، بغداد، العراق

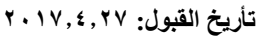

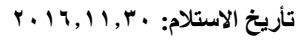

الخلاصة

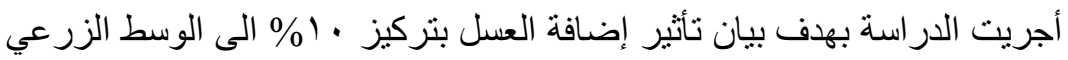

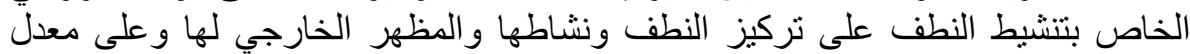

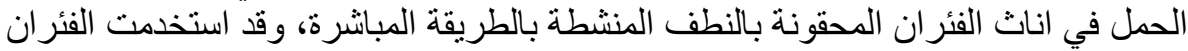

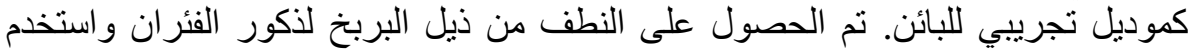

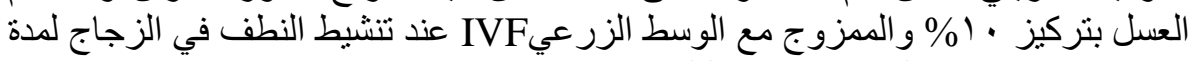
نصف ساعة ثم حقن النطف بطريقة التلقيح الاصطناعي.

أظهرت النتائج ان اضافة العسل الى الوسط الزرعي قد أثر تأثيراً إيجابياً على حركة

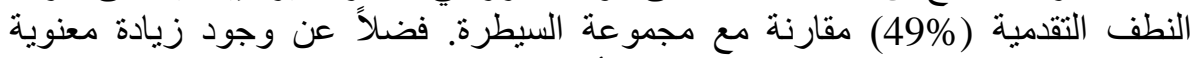

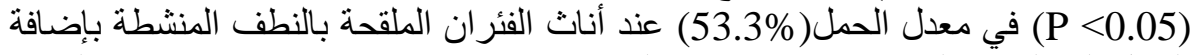

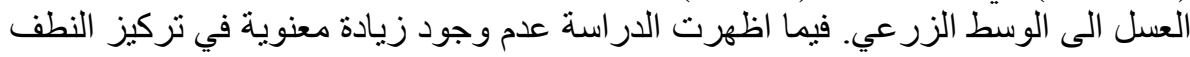

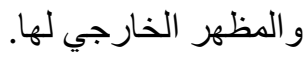

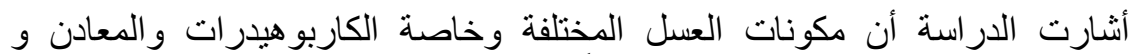

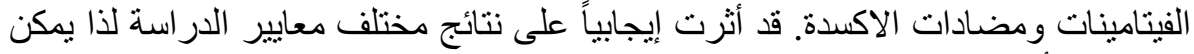

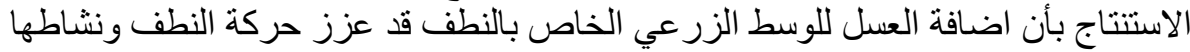

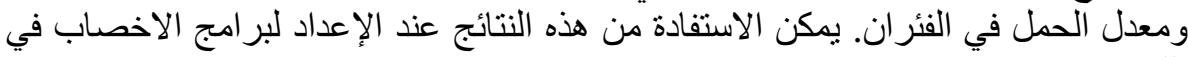

